\title{
Developmental and educational goals of early childhood education and care - perspective of Warsaw caregivers ${ }^{1}$
}

\begin{abstract}
The following inquiry aims at exploring the beliefs of caregivers from the Public Crèche Network in Warsaw, the biggest network of this type in Poland, on the importance of fostering different developmental and educational goals in the youngest children. The participating caregivers $(\mathrm{N}=449)$ completed a structured, Internet-based questionnaire on the significance of supporting the development of social, cognitive, physical, emotional and personal goals of 0-3-year-olds in early childhood settings. Also, information on practitioners' educational background and work experience was collected to investigate whether their beliefs differed depending on these background characteristics. The results revealed no associations between the caregivers' beliefs and their formal pre-service training (higher education diploma vs none or vocational training) or their work experience (5 years or less experience of work in early childhood settings vs over 5 years of work in the ECEC sector). The findings of the study are discussed with regard to the Polish legal context and potential practical implications.
\end{abstract}

Keywords: early childhood education and care, beliefs, educational and developmental goals, caregiver.

\footnotetext{
${ }^{*}$ Faculty of Education, University of Warsaw.

${ }^{1}$ The study presented in this article was conducted with a grant from the European Union's Seventh Framework Programme for Research, Technological Development and Demonstration under grant agreement No. 613318 and from the national funds for science in the years 2014-2016 for the co-financing of international projects. The article is a part of a PhD dissertation project. I would like to thank my promotor Professor Małgorzata Karwowska-Struczyk from the Faculty of Education of University of Warsaw and my co-promotor Pauline Slot, PhD, from the Faculty of Social Sciences of Utrecht University for their theoretical, methodological and editorial advice.
} 


\title{
Cele rozwojowe i wychowawcze w edukacji i opiece wczesnodziecięcej - perspektywa warszawskich opiekunów
}

\begin{abstract}
Abstrakt
Celem badania jest eksploracja poglądów wychowawców z Zespołu Żłobków m.st. Warszawy, największej tego typu sieci w Polsce, na temat ważności wspierania różnych celów rozwojowych i edukacyjnych w pracy z najmłodszymi dziećmi. Wychowawcy $(\mathrm{n}=449)$ wypełnili internetowy, ustrukturyzowany kwestionariusz ankiety na temat wspierania rozwoju społecznych, poznawczych, fizycznych, emocjonalnych i osobistych umiejętności dzieci do 3 lat, podczas ich pobytu w żłobku. Ponadto w badaniu uwzględnione zostały informacje dotyczące wykształcenia praktyków i stażu ich pracy. Wyniki sugerują, że nie ma związku między poglądami wychowawców i ich formalnym przygotowaniem do wykonywania zawodu opiekuna dziecięcego (dyplom uczelni wyższej vs brak wykształcenia lub wykształcenie zawodowe w obszarze wczesnej opieki, wychowania i edukacji) oraz długości stażu pracy (5 lub mniej lat pracy w sektorze vs więcej niż 5 lat pracy w sektorze). Rezultaty badania omówione są w odniesieniu do regulacji prawnych sektora wczesnej opieki, wychowania i edukacji dzieci w Polsce oraz potencjalnych implikacji praktycznych.
\end{abstract}

Słowa kluczowe: wczesna opieka wychowanie i edukacja, poglądy, cele rozwojowe i edukacyjne, wychowawca małego dziecka.

\section{Introduction}

The first years of life are a crucial period for human development. Approximately up to the age of four years the children's brain is the most susceptible to experiences shaping the foundations of peer social skills, emotional control, numbers and symbols understanding, language, habitual ways of responding, vision and hearing (Council for Early Child Development 2010: 2). In early years, parents, in the majority of cases, are the primary caregivers of a child. Nevertheless, especially in Western societies, an increasing number of children is enrolled in center-based Early Childhood Education and Care (ECEC). Research conducted in the USA and European context shows that young children's socio-emotional and cognitive development can be successfully supported by high quality ECEC provision (Burchinal, Vandergrift, Pianta, Mashburn 2010: 166; Melhuish, Quinn, Sylva, Sammons, Siraj-Blatchford, Taggart 2013: 234). In addition, there is empirical evidence that access to influential early childhood programs may efficiently support disadvantaged families, having a positive impact on health, future children's labor incomes, education and mother's labor income (Garcia, Heckman, Leaf, Prados 2016: 4). Therefore, the importance of providing children with high quality ECEC services has been widely acknowledged. Structural characteristics of ECEC, such as educational qualifications of practitioners or the context of the provision are considered important prerequisites for high quality services, although the 
evidence is mixed (Kuger, Kluczniok, Kaplan, Rossbach 2016: 4). What is widely recognized though, is that the quality of provision is directly related to children day-to-day experiences in a setting (Pianta, Hamre 2009: 112) and practitioners' beliefs are relevant for shaping these experiences (Palardy, Rumberger 2008: 130).

\section{Beliefs of teachers}

The concept of beliefs is considered to be complex, hard to define and often daunting to distinguish from the concept of knowledge (Pajares 1992: 309). Nevertheless, most definitions of this personal construct share a common assumption that "a belief is based on evaluation and judgment; knowledge is based on objective fact" (ibidem: 313). The system of beliefs is built on one's experiences and affections. It functions as a hierarchical system, where beliefs that are more central and better connected with other beliefs are harder to influence, whereas beliefs further from the center of this system are more receptive to changes (Rokeach 1973: 5). Pedagogical beliefs of teachers start to be structured from their first contact with the educare system. This includes indirect contact, such as listening as a child about older siblings' fears of math classes, and direct experiences as a student, teacher candidate and, finally, as a qualified practitioner.

Due to the terminological bias, educators' beliefs, which have frequently been the subject of educational research, are usually operationalized for the purpose of a particular inquiry. As a result, objectives of these studies are components of belief systems referring to the specific fields of a teacher's activity for example, teacher's pedagogical beliefs regarding the efficiency and effectiveness of ICT (Petko 2012). A different approach to the exploration of beliefs refers to the investigation of relations between different beliefs. For instance, research by Deborah Stipek and Patricia Byler shows that pedagogical beliefs of ECEC practitioners about effective practices are related to their opinions on the importance of different goals for children in a setting. Specifically, preschool professionals who believe in the successfulness of a child-centered approach considered independence and a positive self-concept as important goals (1997: 313). Furthermore, research indicates associations between ECEC practitioners' beliefs and their day-to-day practices (Fang 1996: 52). Given the importance of practitioners' beliefs it is significant to identify possible determinants of these beliefs in view of changing these beliefs, and ultimately affecting professionals' practices. Practitioners' characteristics and the wider context can potentially influence their beliefs, as will be outlined below.

\section{Characteristics of ECEC practitioners}

Professional development (PD) is positioned among the structural characteristics of ECEC provision, which are considered to be pre-conditions of process quality, and more specific children day-to-day experiences in a setting (Cryer, Tietze, 
Burchinal, Leal, Palacios 1999: 339-340). The concept of PD refers to the actions aimed at developing, improving, optimizing, modifying, and enriching the existing situation with regard to the knowledge, skills or responsibilities of practitioners (Telka 2005: 355). Ultimately, the level of PD effectiveness is reflected by children's outcomes (Sheridan, Edwards, Marvin, Knoche 2009: 379). PD initiatives include initial (pre-service) and on-going (in-service) training.

Along with teacher-to-children ratio and group size, pre-service training is considered a pillar of the 'iron triangle' of structural variables (Phillipsen, Burchinal, Howes, Cryer 1997: 281). Therefore, a number of studies have explored its relations with children's experiences in a setting. For instance, a review by Diane Early et al. of seven studies of Preschool Programs in the USA has shown null or contradictory associations of practitioners' formal pre-service training with process quality (2007: 558). In the European context, more specific in the Netherlands, recent research has shown a small positive association of the pre-service educational level of ECEC practitioners and emotional process quality (Slot, Leseman, Verhagen, Mulder 2015: 64). However, another study in the Dutch context showed no such associations (Vermeer, van Iizendoorn, de Kruif, Fukkink, Tavecchio, Riksen-Walraven, van Zeijl 2008: 375). A possible explanation of these mixed results has been provided by Sharon Kagan and Michelle Neuman who reviewed three large scale American studies, namely the National Day Care Study (NDCS), the National Child Care Staffing Study (NCCSS) and the Cost, Quality, and Child Outcomes Study (CQCO) and indicated that the relation of ECEC practitioners' qualifications with process quality is stronger when their training is specifically focused on ECEC contents (1995: 66).

\section{The context of ECEC provision - theoretical background}

Even though the most meaningful for children's development are direct nonepisodic interactions, which take place for extended periods of time (Bronfenbrenner 1994: 39), also the indirect influences are relevant, as they provide the context for these interactions. Bronfenbrenner describes the conditions of human development as "the ecological environment conceived as a set of nested structures, each inside the other like a set of Russian dolls" (ibidem). The theoretical framework is framed by the assumption that human environment may be divided into five structures. Starting from the closest to a person there is the microsystem that concerns the relations of a person with family members, caregivers, peer group etc. Following it is the mesosystem including all relations between the groups of the microsystems, for example parents and ECEC practitioners. The next structure is the exosystem that concerns relations between groups, which are directly and indirectly related with a person, such as cooperation of an ECEC setting with an NGO organization resulting in receiving a grant for a new playground that a child will visit. The furthest from a person is the macrosystem regarding customs, life 
style, political regulations, and the value system of the micro-/meso-/exo-/systems. The last structure is the chronosystem, which is made up of major life transitions, historical events that influence the interactions of a person with all the other structures, for instance for a child it may be a divorce of parents.

Among the most easily regulable components of the ECEC system are legal Requirement, which in accordance with the Bronfenbrenner's theory are positioned in the macrosystem. Educational policy makers, by modifying steering regulations, may shape the ECEC provision on a large scale, for example by indicating goals, establishing qualification requirements or architectural guidance.

\section{Polish legal and demographic context}

In Poland, the ECEC system is split into two sectors according to the age of children, more specific there are settings for children aged 0-3 and 3-6 (there is an overlap of 3-year-old children). In 2011, a highly important legal modification concerning the supervision over the educare sector of the youngest children took place, as it was moved from the Ministry of Health to the Ministry of Family, Labor and Social Policy. This change has had a great influence on the character of ECEC settings by changing their role from medical facilities to institutions providing care, upbringing and education. The new organization of the sector is still under discussion and the act is being (re)developed yearly. Nevertheless, acknowledging the educational function of settings and consequently opening access to a career of a caregiver to professionals with non-medical training (pedagogues with different specializations) resulted in large diversification of caregivers' qualifications and has been an impetus for opening a public debate on the role of educare for the youngest children and its potential place in the educational system.

The change of the supervision over the sector has been conducted along with simplifying the rules for establishing settings. This has caused a rapid growth in the number of settings, and, has positioned the institutional educare as an increasingly important context for the development of the youngest children in Poland. The number of children enrolled in different forms of center-based educare has been systematically rising, in 2010 it was on the level of $2.6 \%$, whereas in 2015 this number rose to $8.3 \%$ and the estimated rate for 2016 is calculated on the level of 9.3\% (Sprawozdanie Rady Ministrów 2015: 18, 38). In addition, the amount of time spent by children in ECEC settings in Poland is on average over 39 hour per week, which is the second highest average in Europe (Eurostat 2014: 69).

\section{Pedagogical framework and work organization of Polish crèche settings}

New legal regulations concerning goals and desirable practices of ECEC provisions for the youngest children are very limited. The steering document for the sector Ustawa o opiece nad dziećmi w wieku do lat $3 \mathrm{z}$ dnia 4 lutego 2011 [Act of 4 Febru- 
ary 2011 on the care for children under the age of three], settles only general guidelines indicating the need for providing children in ECEC settings with educare activities appropriate for their age, individual and developmental needs (ibidem, Art. 10). Establishing statutes including specific goals, tasks and the ways of their implementation is the responsibility of each setting founder (ibidem, Art. 11), which in terms of public institutions is a municipality. Nevertheless, no specific legal requirements toward the status have been formulated.

Legal changes influenced also the proportion of public and non-public providers, which since 2013 has been in favor of the non-public services. A great majority of non-public settings work as individual entities, whereas public ones of big municipalities often work as networks. By the end of 2015, 182 of 531 public settings in the country worked within 26 networks (Informacja dotycząca realizacji ustawy o opiece nad dziećmi w wieku do lat $3 \mathrm{w}$ okresie od 1 lipca do 31 grudnia $2015 \mathrm{r}$. [Information on the implementation of the Act on the care of children under the age of 3 in the period from July 1 to December 31, 2015.]).

The biggest public crèche network in Poland is Zespół Żłobków m.st. Warszawy (Public Crèche Network in Warsaw) with 52 settings (data as of the end of 2015) and 8 new investments under realization. The institution is supervised by the Director (municipality representative). In general, working conditions, such as salaries or promotion system, are alike in all crèches. Nevertheless, each setting has got its own supervisor and works rather autonomously in terms of day-to-day practices. The settings operate in very different neighborhoods (low SES families, 'new neighborhoods' with rather young inhabitants, etc.), consequently the specificity of challenges and resources vary between them.

\section{Methodology}

This study builds on the premises presented in the previous sections by exploring the relations of the ECEC system characteristics, which have been shown to be influential for practice, more specific caregivers' beliefs and the relations of these beliefs with caregivers' qualifications and legislation change.

For the purpose of the following inquiry the term 'beliefs' was operationally defined as referring to the self-reported opinions of practitioners reflecting their view on the ECEC goals, specifically concerning the importance of fostering different educational and developmental goals in children. In this study, the concept of developmental goals refers to the objectives connected to shaping socially promoted attitudes and self-regulation skills, for example controlling one's own emotions, whereas educational goals concern objectives closely related to the school domains, such as literacy, math and science. 


\section{Aim of the study and research questions}

The aim of this study is to explore the opinions of professionals from the Public Crèche Network in Warsaw (further referred to as "the Network") with different educational backgrounds and work experience on the importance of fostering social, cognitive, emotional, personal and physical goals in 0-3-year-old children in the ECEC settings. The following research questions were formulated: (1) What do caregivers view as important goals for children concerning social, cognitive, physical, emotional, and personal development in ECEC?; (2) Do caregivers' beliefs differ depending on their educational background (i.e. higher education diploma Vs none or vocational training)?; (3) Do caregivers' beliefs differ between professionals who had/have been working in the ECEC settings before and after the legal change of the crèche educare sector?

\section{Variables specification}

Two independent variables are taken into consideration. The first one is the preservice qualifications level of practitioners indicated by the highest achieved qualification (higher education diploma Bachelor or Master Vs none or vocational training). The educational categories refer to the national discussion on the need of rising qualification requirements for caregivers to the minimum of Bachelor degree. The second one is work experience of practitioners indicated by years of work in the ECEC sector ( 5 or fewer years of work in the ECEC sector Vs over 5 years of work in the ECEC sector). This division of more or less than 5 years of work experience was chosen because it divides practitioners into two groups of those who had/have worked before and after the legal acknowledgment of the educational function of ECEC settings for the youngest children in Poland (see: the Pedagogical framework and work organization of Polish crèche settings section). Dependent variables are the opinions of professionals on the survey questions concerning the importance of fostering the development of social, cognitive, emotional, personal and physical goals in children aged 0-3 years in the ECEC settings. The opinions were scored by the caregivers on a five-point Likert scale.

\section{Participants}

The following inquiry has drawn data from the Stakeholders Study conducted within the Curriculum Quality Analysis and the Impact Review of European Early Childhood Education and Care project (CARE; ecec-care.org), more specific the Internet-Based Survey. Of the available dataset, a group of professionals was selected, namely practitioners from the Network. At the time of data collection 
(year 2015) 974 caregivers worked in the Network of whom 449 (46.1\%) completed the questionnaire. All respondents were women. Table 1 presents descriptive statistics for professional characteristics.

Table 1. Descriptive statistics for professionals characteristics

\begin{tabular}{|l|c|c|c|c|}
\hline & N & M & SD & Range \\
\hline Age (in years) & 442 & 39.9 & 10.7 & $21-68$ \\
\hline Work experience in ECEC settings (in years) & 444 & 11.4 & 10.6 & $0-45$ \\
\hline Frequency (N)/ Percent (M) & & $\%$ & - & - \\
\hline Non or vocational training & 255 & 56.8 & - & - \\
\hline Bachelor or Master degree & 188 & 41.9 & - & - \\
\hline
\end{tabular}

Source: author's own research.

\section{Self-reported opinions of caregivers regarding goals of ECEC services}

A structured, internet-based survey (IBS) was used to collect practitioners' opinions on the importance of fostering different developmental and educational goals in children aged 0-3 years in the ECEC settings. This measure, collaboratively constructed by the European researchers for the purpose of the CARE project, was originally elaborated in English. To assure accuracy of the Polish version of the tool, the following steps were undertaken: translation of the tool (aimed at the conceptual equivalent, not a word-for-word translation), expert panel, back-translation of 'problematic' parts of the questionnaire and a pilot study (for more information on the survey see: www.ecec-care.org). The developmental and educational goals included in the IBS cover a range of skills, abilities and attitudes and were grouped into five scales. The "Social development scale" (11 items; $\alpha=0.94$ ) includes goals that are important for building children relations with others and being a member of different social groups. An exemplary item is: "Has a sense of autonomy/independence". The "Development of thinking, language and math scale" (10 items; $\alpha=0.91$ ) covers goals important for children's cognitive development, for instance: "Is interested in knowledge of the physical world". The "Physical development, skills and health scale" (8 items; $\alpha=0.88$ ) consists of items referring to children small and gross motor skills and their physical condition and habits, for example: "Has healthy eating habits". The "Emotional development scale" (5 items; $\alpha=0.87$ ) includes items concerning self-regulation skills. An exemplary item is: "Develops control of his/her emotions". The "Personal development scale" (5 items; $\alpha=0.88$ ) covers competences regarding children individual growth with items such as: "Is open-minded, not afraid to try new things". Practitioners assessed the importance 
of each goal on a 5-point scale, ranging from 1 (unimportant), 2 (of little importance), 3 (moderately important), 4 (important), to 5 (highly important).

\section{Data collection and data analysis}

The process of data collection was preceded by two organizational meetings. The first meeting was participated by the Director, pedagogical supervisor and lawyer of the Network. ; It resulted in establishing the conditions of collaboration between the Network and researchers. Following was a meeting with supervisors of all settings in the city of Warsaw (52 centers) organized by the Director in the Network's headquarters. At this meeting, the researcher presented the general objectives of the study and the IBS and requested supervisors to provide information about the inquiry to practitioners from their centers and to arrange time (it had been agreed with the Director that practitioners would complete the IBS during their working hours) and space (computer with Internet access) for the them to complete the survey.

Initially, the data collection was to last from February till May 2015, however due to the low response rate the deadline was prolonged. To increase the number of participants a round of emails was sent to all settings with a request for engaging in the study. Finally, the data were collected from February till November 2015.

The results from the IBS were statistically analyzed with the SPSS Statistics version 23.0. First, the mean scores for all scales were calculated. Then, a one-way ANOVA technique was used to compare the mean scores for professionals with a degree (Bachelor or Master) and those without higher education diploma (none or vocational training) and caregivers varying in work experience ( 5 or more years of experience Vs 6 or more years of work in the ECEC sector). Finally, a regression analysis was conducted to investigate the interaction effects of caregivers' qualifications and work experience with their beliefs.

\section{Results}

Results based on the IBS reveal that professionals consider fostering four types of goals in children as more than moderately important, but less than important. Emotional development of children is viewed as the most meaningful and it was classified at the level of important. On average, social goals are rated as the second most valuable ones. Slightly less appreciated are the physical goals. The fourth classified group of indicators concerns the personal development of children. One type of goals is rated considerably lower than others, namely cognitive development which is valued more than of little importance, but less than moderately important. The descriptive statistics are shown in Table 2. 
Table 2. Descriptives for the caregivers opinions on the ECEC goals

\begin{tabular}{|l|c|c|c|c|}
\hline & N & M & SD & Range \\
\hline Social development & 399 & 3.91 & 0.75 & $1.1-5$ \\
\hline Cognitive development & 391 & 2.97 & 0.81 & $1.0-5$ \\
\hline Physical development & 414 & 3.86 & 0.66 & $1.5-5$ \\
\hline Emotional development & 422 & 4.00 & 0.70 & $1.6-5$ \\
\hline Personal development & 427 & 3.80 & 0.73 & $1.4-5$ \\
\hline
\end{tabular}

Source: author's own research.

Groups of professionals with higher education diploma and without it rank the importance of different types of goals the same, valuing the most emotional (higher educated: $\mathrm{N}=180, \mathrm{M}=3.94, \mathrm{SD}=0.70$; lower educated: $\mathrm{N}=236, \mathrm{M}=4.03$, $\mathrm{SD}=0.70$ ) then social (higher educated: $\mathrm{N}=168, \mathrm{M}=3.91, \mathrm{SD}=0.71$; lower educated: $\mathrm{N}=226, \mathrm{M}=3.9, \mathrm{SD}=0.79$ ), physical (higher educated: $\mathrm{N}=174, \mathrm{M}=3.89$, $\mathrm{S}=0.65$; lower educated: $\mathrm{N}=234, \mathrm{M}=3.82, \mathrm{SD}=0.68$ ), personal (higher educated: $\mathrm{N}=181, \mathrm{M}=3.84, \mathrm{~S}=0.71$; lower educated: $\mathrm{N}=240, \mathrm{M}=3.77, \mathrm{SD}=0.75$ ) and lastly cognitive (higher educated: $\mathrm{N}=168, \mathrm{M}=3.05, \mathrm{SD}=0.84$; lower educated: $\mathrm{N}=219$, $\mathrm{M}=2.91, \mathrm{SD}=0.79$ ) ones.

Groups of professionals with higher education diploma and without it rank the importance of different types of goals the same, valuing the most emotional (higher educated: $\mathrm{N}=180, \mathrm{M}=3.94, \mathrm{SD}=0.70$; lower educated: $\mathrm{N}=236, \mathrm{M}=4.03$, $\mathrm{SD}=0.70$ ) then social (higher educated: $\mathrm{N}=168, \mathrm{M}=3.91, \mathrm{SD}=0.71$; lower educated: $\mathrm{N}=226, \mathrm{M}=3.9, \mathrm{SD}=0.79$ ), physical (higher educated: $\mathrm{N}=174, \mathrm{M}=3.89$, $\mathrm{S}=0.65$; lower educated: $\mathrm{N}=234, \mathrm{M}=3.82, \mathrm{SD}=0.68$ ), personal (higher educated: $\mathrm{N}=181, \mathrm{M}=3.84, \mathrm{~S}=0.71$; lower educated: $\mathrm{N}=240, \mathrm{M}=3.77, \mathrm{SD}=0.75$ ) and lastly cognitive (higher educated: $\mathrm{N}=168, \mathrm{M}=3.05, \mathrm{SD}=0.84$; lower educated: $\mathrm{N}=219$, $\mathrm{M}=2.91, \mathrm{SD}=0.79$ ) ones.

On average, the higher educated caregivers report slightly more appreciation than the lower educated practitioners for all types of goals except the emotional ones. Figure 1 presents the comparison of self-reported opinions of professionals with different qualifications.

An analysis of variance did not reveal statistically significant effects of type of pre-service qualifications on the caregivers opinions about the importance of fostering in children: social $F(1,392)=0.001 ; p=0.980$, cognitive $F(1,385)=$ 2.858; $\mathrm{p}=0.092$, physical $\mathrm{F}(1,406)=1.062 ; \mathrm{p}=0.303$, emotional $\mathrm{F}(1,414)=$ $1.590 ; \mathrm{p}=0.208$ or personal $\mathrm{F}(1,419)=0.865 ; \mathrm{p}=0.353$ goals. 


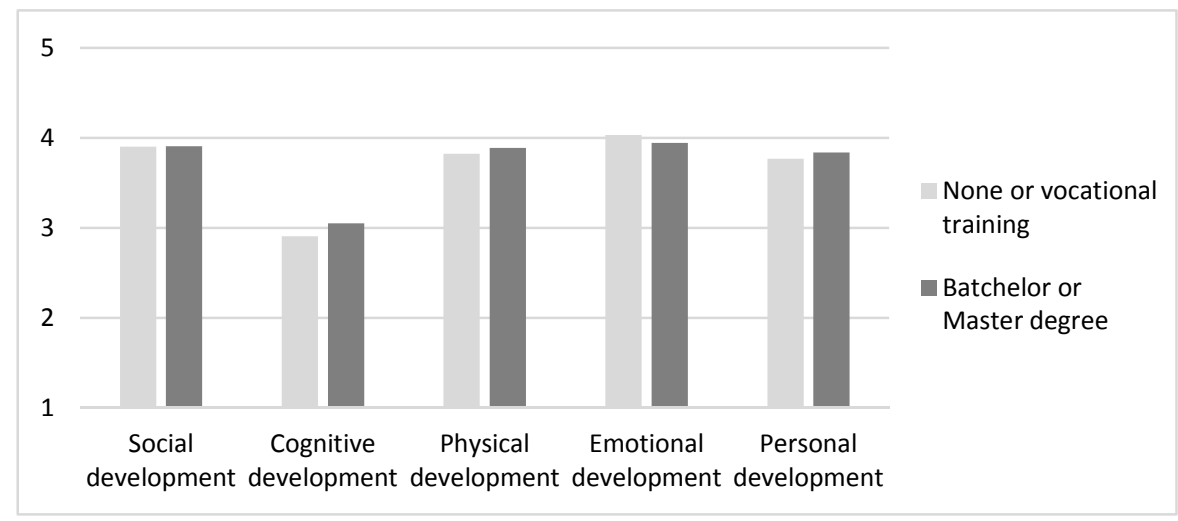

Figure 1. Self-reported opinions of professionals with different pre-service training

Source: author's own research

Groups of practitioners who started working before and after the legal change rank the importance of fostering different goals in children the same way, valuing the most emotional (more experienced: $\mathrm{N}=173, \mathrm{M}=4, \mathrm{SD}=0.66$, less experienced: $\mathrm{N}=244, \mathrm{M}=3.99, \mathrm{SD}=0.73$ ) then social (more experienced: $\mathrm{N}=161, \mathrm{M}=3.94$, $\mathrm{SD}=0.69$, less experienced: $\mathrm{N}=233, \mathrm{M}=3.88, \mathrm{SD}=0.79$ ), physical (more experienced: $\mathrm{N}=172, \mathrm{M}=3.88, \mathrm{SD}=0.65$, less experienced: $\mathrm{N}=237, \mathrm{M}=3.85, \mathrm{SD}=0.68$ ), personal (more experienced: $\mathrm{N}=174, \mathrm{M}=3.81$, $\mathrm{SD}=0.69$, less experienced: $\mathrm{N}=248, \mathrm{M}=3.31, \mathrm{SD}=0.76$ ) and lastly cognitive development (more experienced: $\mathrm{N}=163, \mathrm{M}=3.05, \mathrm{SD}=0.82$, less experienced: $\mathrm{N}=223, \mathrm{M}=2.91, \mathrm{SD}=0.81$ ). On average, caregivers working in ECEC sector for 5 or less years consider all types of goals except personal ones as slightly more important than practitioners with 6 or more years of experience. Figure 2 shows the comparison of self-reported opinions of caregivers with different work experience.

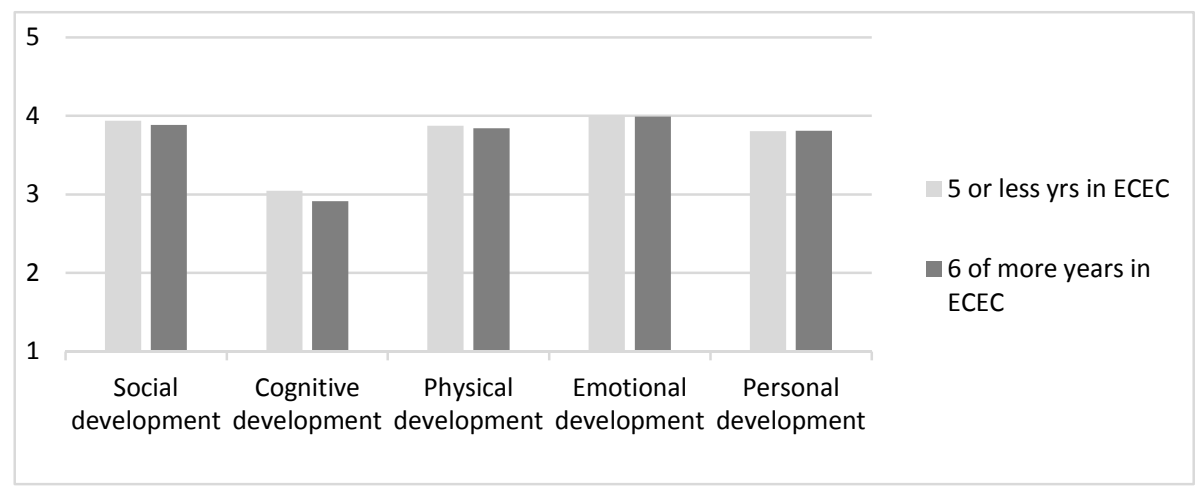

Figure 2. Self-reported opinions of professionals with different work experience

Source: author's own research 
There was no statistically significant difference between the groups of more and less experienced practitioners (caregivers working before and after the legal change) in relation to their opinions about the importance of fostering in children social $F(1,392)=0.507 ; p=0.477$, cognitive $F(1,384)=2.644 ; p=0.105$, physical $F(1,407)=0.203 ; p=0.652$, emotional $F(1,415)=0.011 ; p=0.916$ or personal $\mathrm{F}(1,420)=0.003 ; \mathrm{p}=0.953$ goals as determined by the one-way ANOVA.

Finally, the multiple regression was calculated to predict the opinions of practitioners based on their educational qualifications and work experience. Neither educational qualifications nor work experience were significantly related to practitioners' opinions on social ( $p=0.717$ with an R2 of 0.002$)$, cognitive $(p=0.138$ with an R2 of 0.010 ), physical ( $p=0.599$ with an R2 of 0.003 ), emotional ( $p=0.351$ with an $R 2$ of 0.005 ) and personal ( $p=0.566$ with an $R 2$ of 0.003 ) goals.

\section{Discussion}

This study has investigated opinions of caregivers from the Public Crèche Network in Warsaw on the importance of fostering developmental and educational goals in center-based educare for children aged 0-3 years, and relationships of these opinions with practitioners' educational background and legal regulations concerning the role of ECEC settings.

Self-reports of caregivers reveal that practitioners value different developmental goals, more specifically social, emotional, physical and personal ones, on comparable levels, whereas educational goals are in their opinion considerably less important. Taking into account that the legal change of the educare system concerned introducing an educational component to the ECEC provision for the youngest children, this result is rather alerting. It suggests that caregivers have not revised their pedagogical approach despite the new legal circumstances or that the change of their opinions has been proceeding slowly. Regarding the context of the change, two possible explanations of these findings seem to be worth highlighting. Firstly, the results may be related to the lack of actions, such as in-service training programs, that would support the introduction of the new guideline by encouraging caregivers for revision of their pedagogical approaches. Secondly, new legal guidelines concerning the curriculum are extremely scarce and give caregivers opportunity for intersubjective orientation toward a child and his/her individual needs. Along with the lack of monitoring procedures it leaves a space for marginalizing the educational aspect of the provision. Since the legal change was introduced, many practitioners with a higher pedagogical diploma (different specializations of pedagogical Bachelor or Master studies) have become caregivers. Providing access to the profession to pedagogues has suggested acknowledging the importance of knowledge about psychology and didactics, which are the pillars of the majority of pedagogical university courses in Poland. However, the results of this study suggest 
that practitioners with and without higher educational diploma are consistent in their opinions and view cognitive goals as less important for young children's growth than developmental goals. This uniform approach may be caused by the fact that in Poland development of the youngest children has been rarely a field of pedagogical researchers' interest. This limited interest of academics could, in turn, uphold prevalent folk beliefs that early childhood is primarily about care, trivializing the importance of cognitive growth in the first years of life. However, this situation is slowly changing, which is apparent for instance at pedagogical conferences where presentations concerning this age group occur more frequently. The findings on the relations between work experience (concerning caregivers working before and after the legal change) and educational background revealed that none of the configurations of these characteristics explain practitioners' beliefs. This information may be of particular interest to stakeholders who are considering establishing rules regarding strategies of composing teams of ECEC professionals and rules of their promotion, as it suggests that other criteria should also be taken into account.

The present study combined with the previous research provides a more indepth understanding of practitioners' view on the goals of ECEC provisions and contributes to the discussion regarding the credentials of ECEC practitioners. While the previous research had focused mostly on ECEC professionals' beliefs on developmentally appropriate practices (DAPs), the pedagogical framework reflecting universally acknowledged 'good practices' for three-to-five-years-old children, this study expands the discussion by exploring the perspective of professionals regarding educational and developmental goals of ECEC provision for children aged 0-3. The findings of this inquiry suggest that the level of pre-service qualifications and legal regulations are not related to practitioners' view on the importance of fostering different goals in the youngest children when they are in ECEC settings. Therefore, further research is required to explore the determinants of caregivers' beliefs. Out of many potential directions of studies two seem to be of particular importance. Firstly, it is crucial to enrich the presented quantitative results with qualitative research to gain a more comprehensive view on practitioners' beliefs regarding the role of ECEC services in children's growth, especially in terms of supporting children cognitive development. Secondly, it is essential to complement the study with research on day-to-day practices of caregivers to explore the extent to which practitioners' beliefs and actions are coherent.

\section{References}

Bronfenbrenner U. (1994) Ecological models of human development in: International Encyclopaedia of Education, 3, 2nd ed., Oxford, Elsevier. Reprinted in: M. Gauvain, M. Cole (eds.) (1993) Reading on the development of children, $2^{\text {nd }}$ ed., NY, Freeman: $37-43$. 
Burchinal M., Vandergrift N., Pianta R., Mashburn A. (2010) Threshold analysis of association between child care quality and child outcomes for low-income children in prekindergarten programs, "Early Childhood Research Quarterly", 25, 2: 166-176.

Council for Early Child Development (2010) The Science of Early Child Development, Brief (PDF).

Cryer D., Tietze W., Burchinal M., Leal T., Palacios J. (1999) Predicting process quality from structural quality in preschool programs: A cross-country comparison, "Early Childhood Research Quarterly", 14, 3: 339-361.

Early D., Maxwell K., Burchinal M., Alva S., Bender R. H., Bryant D., Cai K., Clifford R. M., Ebanks C., Griffin J. A., Henry G. T., Howes C., Iriondo-Perez J., Jeon H.-J. Mashburn A. J., Peisner-Feinberg E., Pianta R. C., Vandergrift N., Zill N. (2007) Teachers' education, classroom quality, and young children's academic skills: Results from seven studies of preschool program, “Child Development", 78, 2: 558-580.

European Commission/EACEA/Eurydice/Eurostat (2014) Key Data on Early Childhood Education and Care in Europe. 2014 Edition, Eurydice and Eurostat Report. Luxembourg: Publications Office of the European Union.

Fang Z. (1996) A review of research on teacher beliefs and practices, "Educational Research", 38, 1: 47-64.

Garcia J. L., Heckman J. J., Leaf D. E., Prados M. J. (2016) The Life-cycle Benefits of Early Childhood Programs, "HCEO Working Paper Series", 35.

Informacja dotycząca realizacji ustawy o opiece nad dziećmi w wieku do lat 3 w okresie od 1 lipca do 31 grudnia 2015 r. [Information on the implementation of the Act on the care of children under the age of 3 in the period from July 1 to December 31, 2015.].

Kagan S. L., Neuman M. J. (1996) The Relationship Between Staff Education and Training and Quality in Child Care Programs, Child Care Information Exchange: 65-69.

Kuger S., Kluczniok K., Kaplan D., Rossbach H. G. (2015) Stability and patterns of classroom quality in German early childhood education and care, "School Effectiveness and School Improvement", 27, 3: 418-440.

Melhuish E., Quinn L., Sylva K., Sammons P., Siraj-Blatchford I., Taggart B. (2013) Preschool affects longer term literacy and numeracy: results from a general population longitudinal study in Northern Ireland, "School Effectiveness and School Improvement: An International Journal of Research, Policy and Practice", 24, 2: 234-250.

Pajares M. F. (1992) Teachers' Beliefs and Educational Research: Cleaning Up a Messy Construct, "Review of Educational Research", 62, 3: 307-332. 
Palardy G. J., Rumberger R. W. (2008) Teacher Effectiveness in First Grade: The Importance of Background Qualifications, Attitudes, and Instructional Practices for Student Learning, "Educational Evaluation and Policy Analysis", 30, 2: 111-140.

Petko, D. (2012). Teachers' Pedagogical Beliefs and Their Use of Digital Media in Classrooms: Sharpening the Focus of the "Will, Skill, Tool" Model and Integrating Teachers' Constructivist Orientations, “Computers \& Education”, 58, 4: 1351-1359.

Pianta R. C., Hamre B. K. (2009) Conceptualization, Measurement, and Improvement of Classroom Processes: Standardized Observation Can Leverage Capacity, "Educational Researcher", 38: 109-119.

Phillipsen L. C., Burchinal M. R., Howes C., Cryer D. (1997) The prediction of process quality from structural features of child care, "Early Childhood Research Quarterly", 12, 3: 281-303.

Rokeach M. (1973) The nature of human values, New York, The Free Press.

Sheridan S. M., Pope Edwards C., Marvin Ch. A., Knoche L. L. (2009) Professional Development in Early Childhood Programs: Process Issues and Research Needs, "Early Education and Development", 20, 3: 377-401.

Slot P., Leseman P. P. M., Verhagen J., Mulder H. (2015) Associations between structural quality aspects and process quality in Dutch early childhood education and care settings, "Early Childhood Research Quarterly", 33, 4: 64-76.

Sprawozdanie Rady Ministrów z realizacji ustawy z dnia 4 lutego 2011 r. o opiece nad dziećmi w wieku do lat 3 (Dz.U. z 2016 r., poz. 157) w 2015 r.

Stipek D. J., Byler P. (1997) Early Childhood Education Teachers: Do They Practice What they Preach?, "Early Childhood Research Quarterly", 12, 3: 305-325.

Telka L. (2005) Doskonalenie kompetencji zawodowych opiekunek we wspieraniu rozwoju małego dziecka $w$ żłobku in: Wspólnie z dziećmi. O wspieraniu rozwoju małego dziecka. Praktyka i teoria. Miejski Zespół Żłobków w Łodzi, H. Mazur, L. Przybylska, A. Rudyk, M. Świercz, L. Telka, B. Wolska (ed.), Łódź, Oficyna Wydawnicza Tercja: 354-362.

Ustawa o opiece nad dziećmi w wieku do lat 3 z dnia 4 lutego (Dz.U. z 2011 r., nr 45, poz. 235). [Act of 4 February 2011 on the care for children under the age of three].

Vermeer H. J., van Ijzendoorn M. H., de Kruif R. E. L., Fukkink R. G., Tavecchio L. W. C., Riksen-Walraven, J. M., van Zeijl J. (2008) Child Care in the Netherlands: trends in Quality over the years 1995-2005, "The Journal of Genetic Psychology", 169, 4: 360385. 